for targets and categories by statisticians and epidemiologists, documents such as the Health of the Nation report (Department of Health, 1992) and the literature and correspondence created in its wake, do little to investigate the real motives which impel someone to take his or her own life.

I do not think psychiatrists should be so easily satisfied to accept these frankly crude targets without qualification and without raising political points for discussion. The current moral and political climate engenders despair, and the loss of personal and family security, the impaired quality of existence and the erosion of the sense of conscious, authentic personal responsibility has lead to a weariness of life for which remedy is not easily found. Weariness with life is an emotional and political problem which cannot be treated by less toxic anti-depressants in overdose, or easily set targets.

DEPARTMENT OF HEALTH (1992) The Health of the Nation strategy for health in England. London: HMSO.

PRTChARD, C. (1992) Is there a link between suicide in young men and unemployment? A comparison of the UK with other European Community countries. British Journal of Psychiatry, 160, 750-756.

SARAH HULINE-DICKENS, Child and Adolescent Psychiatry. The Health Clinic, Church Street, Epsom, Surrey KT17 4WP

\section{Psychiatry in Kurdistan}

Sir: I read Dr Berney's article (Psychiatric Bulletin, February 1994, 18, 104-105) with great disappointment. I would remind him that Kurdistan is the northern part of Iraq with a history dating back $\mathbf{5 0 0 0}$ years. Therefore I don't understand what he means by the 'Iraqi Invasion' in 1987.

There are 30 million Kurds living in Turkey, Syria and Iran and only a fraction of that number live in northern Iraq. If Dr Berney is really sympathetic to the Kurdish cause he should ask for the independence of the entire nation of Kurdistan and not just that part of Iraq!

Finally, I think Dr Berney agrees with other observers that Iraq's international integrity must be respected.

M. SHABAN, Hartwood Hospital, Shotts, Lanarkshire

Sir: I am sorry Dr Shaban was disappointed by my description of a visit which was focused on the furtherance of an aid programme. I included superficial comment on the politics and history as far as I felt it necessary to make sense of the account: brought up in Zimbabwe I recognise that this may sound naive.
I accept that Kurdistan is an ambiguous term. Although the Treaty of Sèvres (1920) provided for a wider Kurdistan, it was never ratified and the Treaty of Lausanne (1923) left the Kurds geographically fragmented. The present term refers to the Kurdish Autonomous Region which was established in 1974 with a separate Executive Council; an autonomy which appears to have become confirmed in the aftermath of the Gulf War. I find 'invasion', the term used within the country, quite appropriate for events which had such genocidal fury as to require United Nations intervention with the creation of the safe havens and no-fly zone.

I would agree that tampering with boundaries is complex and dangerous: Iraq's survival of the Gulf War is a witness to that. I cannot be drawn into a discussion of the policies of Turkey and Iran on whose goodwill depends the survival of the programme.

T.P. BERNEY, Prudhoe Hospital, Prudhoe, Northumberland NE42 5NT

\section{Multidisciplinary teams in child and adolescent psychiatry}

Sir: In the article by David Cottrell (Psychiatric Bulletin, 1993, 17, 733-735) he refers to my own views on the subject (Psychiatric Bulletin, 1992, 16, 33). He challenges the concept of all referrals being made to the consultant as unworkable as the consultant would need to assess all the cases. In my paper I indicated that the consultant would decide to whom the referrals would be delegated, after discussion at the team meeting. This process provides the best service for the patients and links the clinician on the team most suited for the needs of the patient. This I feel is the essence of multidisciplinary work.

I am aware that psychologists and others on the team receive referrals directly but these will not be brought to the team unless requested by the clinicians. This would clarify the boundaries between cases referred to the team and those referred to individual clinicians on the team.

Cottrell mentions the need for doctors to take charge, but it is not that doctors need to take charge, rather that, if leadership of multidisciplinary teams are not clear, patients are disadvantaged because of lack of clarity as to who is responsible. Therefore I proposed that, in a hospital setting, the consultant should be team leader, such clarity enabling the team the freedom of function to its optimum.

Working in the Mental Health Service of the Royal Children's Hospital, Melbourne for the past year, I had to apply for the team leader's post which was open to all disciplines. Currently 